\title{
Erratum to: key to species of the genus cryptorhopalum (Coleoptera: Dermestidae) occurring in the greater Antilles with description of six new species from Hispaniola
}

Marcin Kadej ${ }^{1^{*}}$ and Jiri Háva²

\section{Correction}

After the publication of this article (Kadej and Háva 2013) it came to our attention that we had missed out the LSID code to describe new taxa. The relevant code is: urn:lsid:zoobank.org:pub:C46301B7-C609-4943-8146307BD1B33543.

\begin{abstract}
Author details
'Division of Invertebrates Biology, Evolution and Conservation, Department of Evolutionary Biology and Ecology, University of Wrocław,

Przybyszewskiego 63/77, Wrocław PL-51-148, Poland. ${ }^{2}$ Department of Forest Protection and Entomology, Faculty of Forestry and Wood Sciences, Czech University of Life Sciences, Kamýcká 1176, Prague 6, Suchdol CZ-165 21,

Czech Republic.
\end{abstract}

Received: 20 June 2014 Accepted: 20 June 2014

Published online: 11 September 2014

\section{Reference}

Kadej M, Háva J (2013) Key to species of the genus Cryptorhopalum (Coleoptera: Dermestidae) occurring in the Greater Antilles with description of six new species from Hispaniola. Zool Stud 52:5

\section{doi:10.1186/s40555-014-0047-x}

Cite this article as: Kadej and Háva: Erratum to: key to species of the genus cryptorhopalum (Coleoptera: Dermestidae) occurring in the greater Antilles with description of six new species from Hispaniola. Zoological Studies 2014 53:47.

\footnotetext{
* Correspondence: marcin.kadej@gmail.com

'Division of Invertebrates Biology, Evolution and Conservation, Department of Evolutionary Biology and Ecology, University of Wrocław,

Przybyszewskiego 63/77, Wrocław PL-51-148, Poland

Full list of author information is available at the end of the article
}

Submit your manuscript to a SpringerOpen ${ }^{\circ}$ journal and benefit from:

- Convenient online submission

- Rigorous peer review

- Immediate publication on acceptance

- Open access: articles freely available online

- High visibility within the field

- Retaining the copyright to your article

Submit your next manuscript at $\boldsymbol{~ s p r i n g e r o p e n . c o m ~}$ 